\title{
Intellectual Capital and Human Resources as Objects of Accounting and Control
}

\author{
Submitted 14/08/19, 1st revision 14/09/19, 2nd revision 24/10/19, accepted 26/11/19
}

\author{
I.N. Bogataya ${ }^{1}$, I.A. Kislaya ${ }^{2}$, G.E. Krohicheva ${ }^{3}$, M.A. Kuznetsova ${ }^{4}$
}

\begin{abstract}
:
Purpose: The article is aimed at identifying the features of the intellectual capital and human resources as objects of accounting and control, which build a conceptual basis for the development of methodological approaches to forming an accounting and analytical system of commercial organizations, internal control and audit methods.

Design/Methodology/Approach: To achieve this goal, it is necessary to determine the features of the intellectual capital and human resources, to clarify the conceptual apparatus in the research area, to carry out structuring and cascading of accounting and control objects in the research area and to formulate recommendations for the practical application of structured accounting and control objects in the research area.

Findings: Methodological approaches to structuring accounting and control objects in the field of the intellectual capital and human resources have been developed in this research forming an accounting and analytical system of commercial organizations.

Practical implications: The results of the study can be implemented in the accounting practice of commercial organizations. In particular, the developed methodological approaches can be used in the formation of a structured plan of accounts of an economic entity, in internal control and audit, as well as in providing a wide range of audit and consulting services related to intellectual capital and human resources.

Originality/value: The main contribution of this research is the structuring of accounting and control objects in the field of intellectual capital and human resources.
\end{abstract}

Keywords: Intellectual capital, human resources, accounting, control, audit, audit.

JEL code: E29, M49.

Paper Type: Research article.

\footnotetext{
${ }^{l}$ D.Sc., in Economics, Professor of the Department of Audit, Rostov State University of Economics, Rostov-on-Don, bogatyy89@ rambler.ru

${ }^{2}$ Ph.D., Associate Professor of the Department of Accounting, Rostov State University of Economics, Rostov-on-Don, kislaya_irina@mail.ru

${ }^{3}$ D.Sc., in Economics, Professor of the Department of Economic security, accounting and law, Don State Technical University, galina-krokhicheva@yandex.ru

${ }^{4}$ Senior lecturer of the Department of Audit, Rostov State University of Economics, Rostovon-Don, cuzn.mariya2016@yandex.ru
} 


\section{Introduction}

In conditions of digital transformation, it is impossible to improve the efficiency of organizations without human resources, that is, employees of economic entities with various qualities that determine their ability to work for the production of material and spiritual goods. They are the main engine and source of strength of any economic system. The use of employees' knowledge in the production process is one of the most important factors in creating business value. Consequently, human resources are inextricably linked to the intellectual capital. In this regard, it is reasonable to allocate them as a specific object of accounting and control. The rational management of human resources and the intellectual capital on the basis of an adequate accounting and control strategy implemented by economic entities, contributes to improving the efficiency of their activity.

Currently, accounting data on human resources and the intellectual capital disclosed in various types of reports used by economic entities (financial, integrated, social, etc.) are provided to a wide range of users of these reports (Tchaikovskaya and Bystrova, 2011; Parushin et al., 2018). At the same time, the reporting formats used in practice differ significantly from each other, which is due to both management requests and the current legislation requirements.

In this regard, the reliability and quality of this information play an important role, which is ensured not only by compliance with accounting principles, but also by the use of internal control and audit techniques, as well as in some cases by a wide range of audit and consulting services provided by external auditors.

The intellectual capital report is usually a supplement to traditional financial statements and discloses information to external users about approaches to measuring, evaluating, and selecting a smart capital management strategy in order to increase the level of attractiveness for additional investments. Current trends in the expansion of integrated and management reporting formats (based on IFRS, US GAAP, GRI Guidelines for reporting in the field of sustainable development, etc.) contribute to the choice of options for generating information about human resources in reporting (Arifin, 2017). Digital techniques open up wide opportunities for systematizing information about human resources and the intellectual capital and detailing it (Polenova et al., 2019; Belasheva et al., 2018).

It should be noted that in the economic literature, the concepts of "human resources", "human capital", and "intellectual capital" are often used as synonyms, which puts forward the task of ensuring the unity of the terminology base. In addition, modern studies of researchers in economics require adaptation to the peculiarities of forming information about human resources and the intellectual capital within the accounting and analytical system of the organization, as well as the development of internal control and audit methods. To develop conceptual approaches to forming an accounting and analytical system of commercial organizations, internal control and 
audit methods in the field of human resources and intellectual capital, it is necessary to clearly structure the main objects of accounting and control in the study area.

\section{Methodological Approaches Structuring Human Resources and Intellectual Capital}

In modern conditions, three basic approaches to accounting human resources and allocation of accounting objects are used. The first approach provides for the allocation of accounting objects such as various areas of investment in human resources, reflected in a separate account with accounting similar to investments in non-current assets (Legenchuk, 2006). In this approach, it is proposed to separate information about various areas of investment in human resources in analytical accounting without their subsequent capitalization and to disclose information about them in the notes to the financial statements (Kuzmenko, 2013). A number of researchers suggest using a mixed version, in which the accounting and analytical system of the organization generates information about objects such as various areas of investment in human resources in analytical accounting without their subsequent capitalization in terms of costs related to the functioning and disposal of human resources, and the rest of the costs are recommended to be reflected as non-current assets with their subsequent capitalization.

In Russia, it is impossible to implement this approach due to the lack of an appropriate regulatory framework that establishes such accounting rules. In accordance with the second approach, a number of researchers suggest considering an object such as the most valuable human resources with its reflection as intangible assets (Ruf and Karimova, 2014). According to the third approach, it is recommended to reflect an object such as human capital on the off-balance sheet account "Non-property intellectual assets" on the sub-account "Human assets". This approach is characterized by a mixture of different accounting objects, which requires the use of a conceptual framework based on the principle of unity of the terminology base. In Russia, the accounting and analytical systems of organizations keep records of labour and salary (Kuznetsova et al., 2017), which provides accounting for the number of employees, accounting for labour costs and various social payments of employers, costs related to labour protection, training and advanced training of employees, etc., (Kulagina et al., 2018).

In order to substantiate the objects of accounting and control, it is necessary to differentiate the concepts of "human resources", "human capital", and "intellectual capital". Human resources are connected to the intellectual capital, which is knowledge, information, intangible assets, and experience that can be used to create value. In the knowledge economy, the intellectual capital is the most important economic resource and value creation factor for an organization (Kyshtymova et al., 2018). 
The intellectual capital is considered by scientists as: 1) knowledge, experience, information, and intellectual property (Brooking, 2001); 2) synthesis of the human, structural, and client capital (Stewart, 2007; Demediuk, 2002); 3) the hidden cost of business (Bagrinovsky et al., 2011).

From the point of view of allocation of the intellectual capital accounting and control objects the structural approach based on the research by Stewart (2007) is of the greatest interest (Figure 1).

Figure 1. The intellectual capital structure (Stewart, 2007)

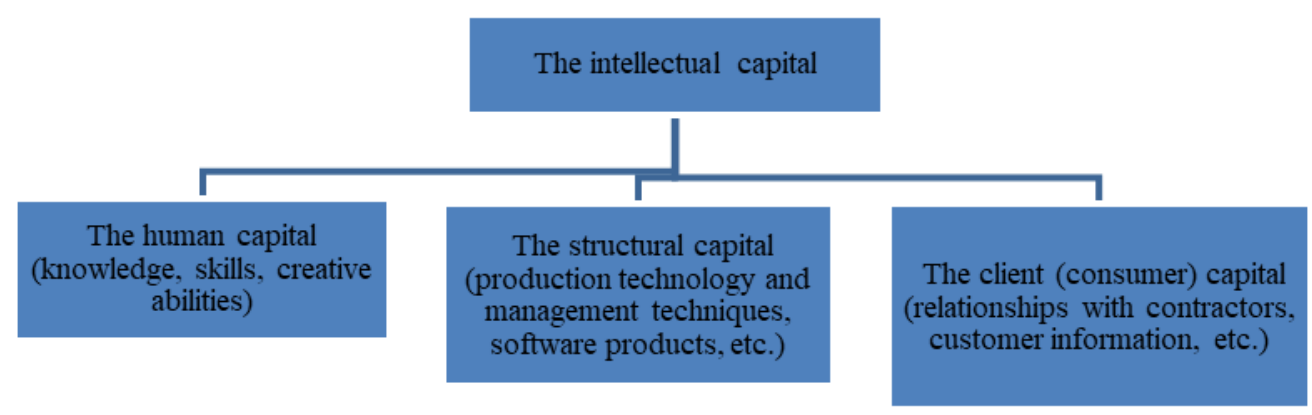

The intellectual capital has a number of features such as: 1) ability to be accumulated, resulting in the fact that the use of knowledge, skills, experience does not lead to their reduction, and, as a rule, has a positive trend; 2) high cost of the formation and use; 3) the venture nature associated with the high-risk of its use in combination with possibilities of high returns from its use; 4) investing in it related to historical, national, cultural features and traditions; 5) high efficiency of investment in the intellectual capital; 6) the ambiguity of its reflection in the accounting system of an economic entity (it is most often reflected in the accounting system as intangible assets whose book value does not correspond to their fair value in Russian accounting practice with a number of the intellectual capital objects not reflected in accounting; 7) control of its use by the person regardless of the investment source in its development; 8) the lack of methods for registering its individual components (for example, the capital of relations); 9) significant differences in the cost of some part of the organizational capital such as patents, licenses in accounting (assessment based on their registration cost) and their real value, determined on the basis of an economic approach (Bogataya, 2019).

The intellectual component, which depends on knowledge and professional competencies, is positioned as human capital with its own creative abilities for the subject. Human capital, as a source of innovation and innovation development, is implemented with the involvement of the subject's organizational system, which uses innovative production technologies and management techniques, information 
resources, software products, and digital techniques together form the structural capital. At the same time, the structural capital turnover may involve its own human capital, when knowledge and experience have become a part of its own intangible assets (know-how, trademarks, software products, techniques), or it may involve the human capital from the outside without transferring ownership rights to the subject. The client (consumer) capital representing the bank with various counterparties and forming the market image of an economic entity plays a crucial role. The human capital in the form of knowledge, experience, competencies is inseparable from a person, able to present the result of knowledge: to transform the result of knowledge into the object of sale, transferring ownership of it to others, or not transferring property rights to the results of knowledge to transfer the right of the advanced techniques using innovation brand with participation in profits.

The real economic return from the realization of knowledge, creative activity and obtaining specific economic benefits cannot, as a rule, be clearly identified. The knowledge agent can be an individual, a group of individuals, a legal entity, or their community. The results of creative activity are documented in the accounting system in the form of technical reports, research reports, patents or certificates. In the legal entities, they are fixed on the basis of patent and copyright law. The complexity of updating the theory of accounting for human resources and the intellectual capital is also related to the duration of the process of turning knowledge into specific technological innovations. Information about human capital and its carriers was not properly reflected in the accounting and analytical support of economic entities.

For example, if the source of the innovation are employees of the organization, then there may be a situation when this innovation, on the one hand, can be accepted on the balance sheet of the subject in the form of a new asset based on the title documents for it. On the other hand, the owner of the innovation (the person-carrier of knowledge) can secure ownership rights to the intangible asset created by him/her. When an innovative product is recognized by different consumers and the cash flow from its use arises, the person-carrier of knowledge needs to participate in additional profits on contractual terms. The higher the probability of obtaining guaranteed value added, the greater the value of the intangible asset and its carrier.

Carriers of an innovative product that are not connected with the owner's labour relations can guarantee additional profit. Contractual obligations with the carrier of innovative knowledge document the terms of participation of each of the parties in obtaining added value and its distribution. Contractual obligations with the carrier of innovative knowledge document the terms of participation of each party in obtaining added value and its distribution. The carrier of innovative knowledge, not being an employee of the organization, may not be an object of accounting as human resources, since he/she may not be a direct participant in the production process, but his/her remuneration is reflected in the accounting and analytical system of the economic entity. The study of human resources within the accounting and analysis system organization is possible from two perspectives: 1) innovation output (patent, 
know-how) becomes the property of the organization; 2) this output does not become property of the organization, but the organization is interested in it in connection with the possibility of obtaining added value.

The finished results of intellectual work acquired on property rights are reflected in the Russian accounting practice in accordance with the Federal Accounting Standard 14/2007 "Accounting of intangible assets". The second variant of creative activity of human resources is not properly reflected in the accounting and analytical system of economic entities. The basis of the knowledge economics is a huge investment in human capital and information techniques, but they are not positively reflected in the traditional accounting (Stewart, 2007).

Taking into account the creative role of knowledge and person-carrier of knowledge in the formation of additional value of the company, it is important to clarify the economic essence of the human capital for their accounting. In our opinion, the human capital as an object of accounting is an asset of the organization in the form of innovative knowledge, which is different from other knowledge used in the industry, and certified by technical, economic or other documentation confirming the possibility of obtaining economic benefits from bringing these innovative knowledge. Figure 2 shows the relationship between external and internal human resources with the structural and customer (consumer) capital.

Figure 2. The relationship of external and internal human resources with the intellectual capital

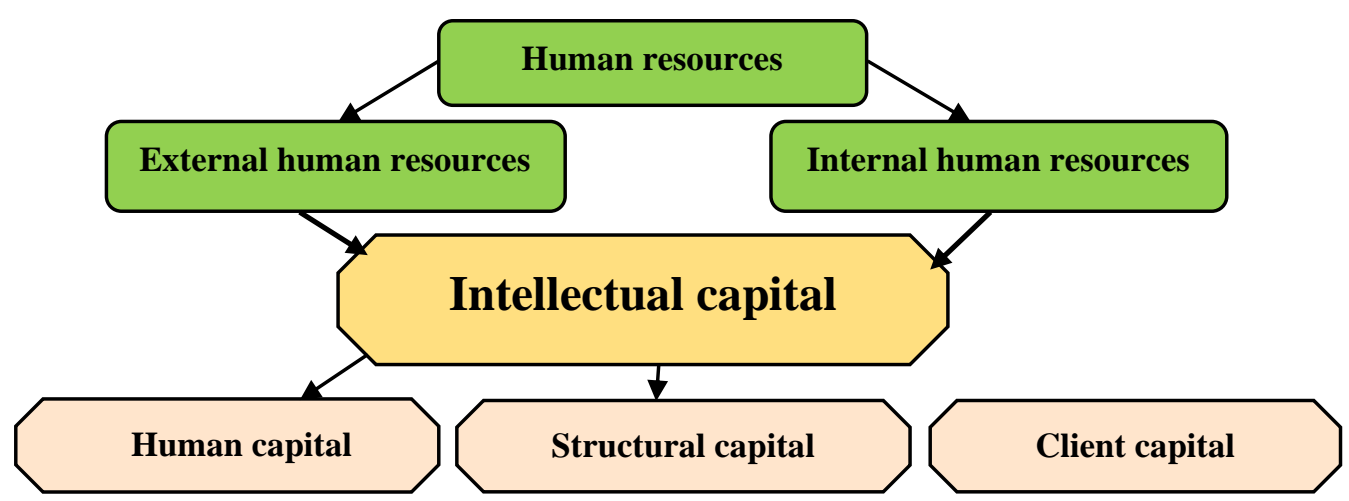

The human capital is closely related to the structural capital, while being a part of the intellectual capital. The human capital carrier is certain people, who in the human capital theory can be called the personal (physical) capital. Involving the human capital carrier in production is the proof of the innovative knowledge conversion into added value, distributed on favorable terms between the owner of the creative activity output and the economic entity owner. Together, the personal and intellectual capital are human resources (Figure 3). 
Figure 3. The relationship between human resources and the intellectual and personal capital

\begin{tabular}{|c|c|}
\hline Intellectual capital & Personal capital (physical) \\
\hline $\begin{array}{c}\text { Innovative knowledge different from other } \\
\text { knowledge in the same industry, } \\
\text { confirmed by technical, economic or other } \\
\text { documentation, etc. }\end{array}$ & $\begin{array}{c}\text { Carriers of innovative } \\
\text { knowledge that guarantee the } \\
\text { conversion of human capital } \\
\text { into added value, affecting the } \\
\text { increase in profits }\end{array}$ \\
\hline The accounting and control object that combines the intellectual and personal capital \\
involved in the organization's reproductive activity
\end{tabular}

However, regardless of the characteristics of the above categories, all of them are united by the category of knowledge. Thus, within the accounting and analytical system of an economic entity, it is necessary to allocate objects of accounting such as employees of the organization for the use in personnel accounting, the intellectual capital in the context of its main components (human capital, structural capital, client (consumer) capital. At the same time in the registration-analytical system depending on the requirements of the current legislation costs associated with the activities of human resources (costs of labor, training, etc.), estimated liabilities associated with vacation pay, obligations to payroll, intangible assets as the results of intellectual, creative activities of employees should be allocated as independent objects. This approach corresponds to the structuring recommended by the current Russian Federal law "On accounting" No. 402-FL.

\section{Methodological Approaches Structuring Control Objects in Relation to Intellectual Capital and Human Resources}

Accounting information generated within the organization's accounting and analytical system about human resources and the intellectual capital can become an object of control. In this case, it is possible to select objects similar to the accounting objects we have highlighted above in the field of human resources and the intellectual capital. In Russia, many public joint-stock companies disclose information about human resources and the intellectual capital in various types of reporting (financial, social, etc.). These reports can be the subject to control and audit. The objects of control and audit can be components of the intellectual capital such as the human capital, structural capital and client (consumer) capital. In relation 
to the structural capital as an object of control, compliance audit can be used in the organizational structure, technical and software, the management system as a whole and its individual elements. At the same time, the human capital use in various organizational systems is evaluated based on the of information transformation into values repeatedly used in the production and economic process.

Control and audit of the structural capital in the form of intellectual property audit, which includes various types of intangible assets (patents, license agreements, etc.) ensuring the growth of business value in the future, is the most widespread. In addition to the intellectual property audit, it is necessary to monitor and audit business processes, as well as information systems used for information exchange and ensuring the creative application of common knowledge), as well as audit strategies, i.e., in addition to compliance audit the intellectual capital audit is interlinked with business process audit and strategic audit. As a part of the control and audit of the client capital, certain components of intangible assets are examined.

They are trademarks, service marks, brand names, goodwill. However, it is illegal to reduce the control and audit of the intellectual capital exclusively to the study of such an object as intangible assets. Assessing the client's trustworthiness in order to comply with the principle of due diligence becomes very important, it makes it possible to assess the risk of unreliability of potential clients and to develop measures of reducing it. The results of the audit of the capital of the relationship it makes possible to determine the position of the business entity, assess the possibility of profit and additional value associated with the relationship with interested parties.

The emotional capital as an integral part of the relationship capital within audit activity is not investigated (Bogataya, 2019). Brooking reduces the intellectual capital audit purpose to its control (Brooking, 2001). Internal audit of the intellectual capital and human resources is aimed at effective management of human resources, knowledge and innovation (Ajupov et al., 2016, Abeysekera, 2001). Control and audit of human resources and the intellectual capital is not limited to accounting information, it is also based on forecast and non-financial information. In the context of digitalization, the role of forecast information, and, consequently, its control and audit, increases. All the objects of control and audit can be classified according to a number of features: 1) by time orientation (objects related to past facts of economic life, objects related to the present time, objects related to planned facts of economic life); 2) in accordance with the subject of the audit available from the international standards on auditing and investigated within specific audit objects.

In accordance with the ISA, the subject of an audit of the intellectual capital and human resources can be: the results of their use and their individual components; their financial position; their condition; descriptions in terms of regulations in the field of human resources and intellectual capital; their structure, as well as business processes related to their use; their functioning/performance; compliance with the requirements set for them. 
The main objects of audit of the intellectual capital and human resources in accordance with ISA are:

1) reporting of the intellectual capital, human resources, or separate statements containing information about them;

2) the objects as a set of business transactions, the facts of economic activity in the implementation of business processes related to the functioning of the intellectual capital and human resources, reflected in the accounting and management system of a commercial organization intangible assets, liabilities, sources of financing, income, costs related to investments in intellectual capital, human resources, other objects;

3) regulations of the organization related to the intellectual capital and human resources;

4) objects that affect the functioning of a commercial organization (systems that affect the process of making strategic and tactical decisions regarding the intellectual capital and human resources, external factors of the macro environment and internal factors that affect the use of intellectual capital and human resources). These objects can be successfully used for internal control and internal audit.

\section{Conclusion}

Thus, the effectiveness of the use of intellectual capital and human resources depends on the quality of information generated within the accounting and analytical system of the organization including a clear allocation of the main objects of accounting and control. The proposed methodological approaches to the structuring of accounting and control objects in relation to human resources and the intellectual capital contribute to the implementation of the main goals of their management on the basis of reliable and detailed information in accordance with the requests of management and the requirements of the current legislation, which are to provide the organization with timely and high-quality human resources, create conditions for the maximum realization of employees' abilities and the effective use of the intellectual capital, this contributes to the implementation of the strategy chosen by the economic entity.

Monitoring and auditing on the basis of the proposed structuring of objects in the field of the intellectual capital and human resources will allow to assess the effectiveness of their use in terms of creating value, as well as to develop recommendations aimed at implementing the reserves identified in the audited area and further improving the organization's business processes.

\section{References:}

Abeysekera, I.A. 2001. Framework to Audit Intellectual Capital. Available online: http://citeseerx.ist.psu.edu/viewdoc/download?doi=10.1.1.456.5040\&rep=rep1\&type= pdf 
Ajupov, A.A., Kurilova, A.A., Azarskaya, M.A., Yakovleva, L.Y., Serebryakova, T.U. 2016. The Formation of the System of internal audit in the Automotive Industry. Research Journal of Applied Sciences, 11, 1166-1171.

Arifin, A.Z. 2017. The influence of financial knowledge, control and income on individual financial behavior. European Research Studies Journal, 20(3), 635-648.

Bagrinovsky, K.A., Bendikov, M.A., Frolov, I.E., Khrustalev, E.Yu. 2011. The High-tech Sector of the Russian Economy: State and Features of the Development. Moscow, RAS publ., 120.

Belasheva, I.V., Shapovalov, V.K., Ershova, D.A., Lozhechkina, A.D., Tereschenko, E.V. 2018. Individual personality traits as predictors of intra-organizational vertical career growth of employees. European Research Studies Journal, 21(S2), 294-304.

Bogataya, I.N. 2019. The Intellectual Capital as an Object of business audit. Modern Problems and Ways of the Development of Accounting, Analysis, Audit and Statistics in Domestic and Foreign Practice: Proceedings of the International Scientific and Practical Conference, Rostov-on-Don, 104-112.

Brooking, E. 2001. The Intellectual Capital: the Key to Success in the New Millennium. Saint Petersburg, Peter Publishing, 288.

Demediuk, P. 2002. The Intellectual Capital Reporting: New accounting for the New Economy. Asian Academy of Management Journal, 1.

Gargate, G., Siddiquee, Q., Wingkar, C. 2018. Intellectual Property Audit of an Organization, https://onlinelibrary.wiley.com/doi/full/10.1111/jwip.12112

Iskhakova, E.I. 2011. A Comprehensive Approach to Intellectual Property Management in the Enterprise. Innovation and Investment, 3, 164-168.

Kulagina, N.A., Bobryshev, A.N., Sulumov, S.Kh., Chaikovskaya, L.A., Smirnov, A.V. 2018. The Personnel Potential of the Agrarian Sector of the Economy of the South of Russia: Regularities and Prospects of the Development. Research Journal of Pharmaceutical, Biological and Chemical Sciences, 6, 1321-1328.

Kuzmenko, O.A. 2013. The Human Capital as an Object of Accounting and Reporting. Questions of Economics and Law, 12, 170-174.

Kuznetsova, E.V., Bogataya, I.N., Khakhonova, N.N., Katerinin, S.P. 2017. Methodology of Building up the Accounting and Analytical Management Support for Organizations in Russia. European Research Studies Journal, 20(1), 258-269.

Kyshtymova, E., Parushina, N., Lytneva, N., Polyanin, A., Plotnikov, V. 2018. The value of the company and transformation of its evaluation under the influence of informatization. Proceedings of the 32nd International Business Information Management Association Conference, IBIMA 2018 - Vision 2020: Sustainable Economic Development and Application of Innovation Management from Regional Expansion to Global Growth, 4395-4407.

Legenchuk, S.F. 2006. Accounting Display of the Intellectual capital: Unpublished master theses in Economics. Zhytomyr, 264.

Parushin, A., Parushina, N., Lytneva, N., Polyanin, A., Vertakova, Y. 2018. The Factor Analysis Technique of Stakeholders' Influence to Form Companies' Shareholder Value. Proceedings of the 32nd International Business Information Management Association Conference, IBIMA 2018 - Vision 2020: Sustainable Economic Development and Application of Innovation Management from Regional Expansion to Global Growth 32, Vision 2020: Sustainable Economic Development and Application of Innovation Management from Regional Expansion to Global Growth, 4408-4423. 
Polenova, S.N., Mislavskaya, N.A., Sotnikova, L.V., Ermakova, M.N. 2019. The Accounting System in Terms of Modern Information Technology. International Journal of Recent Technology and Engineering, 2, 3856-3860.

Ruf, Yu.N., Karimova, D.V. 2014. Accounting for the Organization's Human Resources: Approaches and Problems. Bulletin of Omsk University. Series Economics, 3, 153157.

Stewart, T.A. 2007. The Intellectual Capital. A New Source of Wealth for Organizations. Translated from English. Moscow, Generation, 368 p.

Sukhodolov, A.P., Popkova, E.G., Litvinova, T.N. 2018. Models of Modern Information Economy: Conceptual Contradictions and Practical Examples. Stages of Information Economy's Formation Emerald Publishing Limited. Howard House, 37-46.

Tchaikovskaya, L.A., Bystrova, Yu.O. 2011. The Intellectual Capital in Financial Statements. International accounting, 4(154), 18.

Usenko, L.N., Bogataya, I.N., Bukhov, N.V., Kuvaldina, T.B., Pavlyuk, A.V. 2018. The Formation of an Integrated Accounting and Analytical Management System for Value Analysis Purposes. European Research Studies Journal, 21(S1), 63-71. 